\title{
UPAYA PENGEMBANGAN POPULASI TERNAK BABI MELALUI TEKNIK INSEMINASI BUATAN DIPROVINSI SULAWESI UTARA
}

\author{
Freelce J.Mandey ${ }^{* *}$, U. Paputungan*, E. Pudjihastuti* \\ **Program Pascasarjana, Universitas Sam Ratulangi Manado \\ *Fakultas Peternakan Universitas Sam Ratulangi Manado, 95115
}

\begin{abstract}
ABSTRAK
Tujuan penelitian ini mengevaluasi faktor- faktor dominan yang mempengaruhi upaya pengembangan populasi ternak babi melalui kawin Inseminasi Buatan (IB) di Provinsi Sulawesi Utara. Semen babi pejantan bangsa Landrace, Yorkshire dan Duroc dikawinkan dengan induk Betina bangsa sama melalui IB. Data 345 anak dari 33 induk betina digunakan dalam penelitian ini. Data diperoleh melalui metode pengamatan laboratorium dan lapangan ternak milik masyarakat Kabupaten Minahasa. Data dianalisis dengan uji$t$ melihat pengaruh gender terhadap variabel. Prediksi faktor-faktor reproduksi yang dominan mempengaruhi pengembangan populasi ternak babi kawin IB di Sulut adalahService per conception, Farrowing rate, Efisiensi service IB, dan Farrowing index. Preweaning Average Daily Gain (PW-ADG) kelompok bobot anak lahir inferior $\quad(84,85 \mathrm{~g} / \mathrm{e} / \mathrm{h}) \quad$ nyatalebih rendahdibandingakan bobot anak lahir normal $(86,59 \mathrm{~g} / \mathrm{e} / \mathrm{h})$, tetapi berbeda tidak nyata dengan PW-ADG dari kelompok bobot anak lahir superior $(85,64 \mathrm{~g} / \mathrm{e} / \mathrm{h})$. PWADG kelompok bobot anak lahir superior berbeda tidak nyata dengan PW-ADG kelompok bobot anak lahir normal maupun PW-ADG kelompok bobot lahir anak
\end{abstract}

*korespondensi (corresponding authors)

Email : umarfapet@yahoo.com inferior. Jumlah litter size anak dihasilkan seekor pejantan pada induk betina yang sama melalui kawin alam hanya mencapai rata-rata 21 ekor/tahun, sedangkan jumlah litter size anak dihasilkan seekor pejantan pada induk betina yang sama melalui kawin IB mencapai 225 ekor/tahun.

Kata Kunci:Inseminasi buatan. reproduksi ternak babi, provinsi Sulawesi Utara

ABSTRACT
EXPEDIENCY OF INCREASING PIG
POPULATION BY ARTIFICIAL
INSEMINATION TECHNIQUE IN
NORTH SULAWESI PROVINCE.The
objective of this study was to evaluate
dominant factors affecting pig population
breeding by artificial insemination (AI) in
North Sulawesi province. Semen of boar
(Landrace, Yorkshire and Duroc breeds)
were usedto mate the same breeds using
AI.Data of 345 piglets from 33 sows were
involved in this study. Reproductive data of
sows and productivity of piglet form AI
were observed at laboratory and field
belonging to farmers in Minahasa regency.
Pair data of male and female effect were
analyzed by t-test for variables.Dominant
reproduction factors affecting pig population
breeding in North Sulawesi were
includingservice per conception, Farrowing
rate, AI service efficiency, and Farrowing
index.Group of male and superior piglets
were higher in productivity that those of


female and inferior piglets. Preweaning Average Daily Gain (PW-ADG)groups of inferior $(84.85 \mathrm{~g} / \mathrm{h} / \mathrm{d})$ were significantly lower compared with normal $(86.59 \mathrm{~g} / \mathrm{h} / \mathrm{d})$, butnot significantly different with PW-ADG of superior birth weight group $(85.64$ $\mathrm{g} / \mathrm{h} / \mathrm{d}) . \mathrm{PW}$-ADG.Thelitter size produced from semen bya boar naturally mated with the same sowsreached the average of 21 piglets per year, while those by a boar mated using AI technique with the same sowsreached the average of 225 piglets per year.

Keywords:Artificial insemination. Pig reproduction, North Sulawesi province

\section{PENDAHULUAN}

Dengan semakin meningkatnya kebutuhan bahan pangan asal hewani seperti daging untuk keperluan konsumen, maka perlu adanya upaya peningkatan produksi dan produktivitas ternak antara lain ternak babi. Salah satu faktor yang berpengaruh terhadap produktivitas ternak babi adalah mutu genetis ternak. Oleh karena itu perbaikan mutu genetik harus mendapat perhatian dan menjadi program kegiatan peternakan babi. Inseminasi Buatan (IB) merupakan salah satu yang efektif dan efisien untuk perbaikan mutu genetik ternak.

Di provinsi Sulawesi Utara salah satu jenis ternak yang berkembangbaik dan sesuai kondisi sosial budaya adalah ternak babi, namun dalam perkembangannya peternak babi menggunakan kawin alam dalam mengawinkan ternak. Hal ini dapat berakibat kualitas dan kuantitas bibit ternak babi menjadi kurang baik bahkan dikhawatirkan terjadi inbreeding (Perkawinan antar keturunan).

Inseminasi buatan (IB) merupakan suatu teknik inseminasi pada ternak yang diterapkan secara efisien pada peternakan yang maju (Afiaiti, 2013). Menurut Sihombing (1997), periode yang efektif untuk menginseminasi adalah sekitar 24 jam, antara 24 hingga 36 jam setelah puncak berahi. Pejantan yang akan digunakan dalam IB harus teruji mutunya dalam hal performans, fisik, kesehatan dan manajemen pemeliharaan memenuhi standar (Sihombing, 1997). Seekor babi jantan unggul, dengan IB dapat dipakai untuk melayani 2000 ekor betina per tahun dengan keturunan 20.000 ekor.

Keberhasilan pelaksanaan Inseminasi Buatan (IB) pada ternak sangat tergantung dari kualitas dan kuantitas semen yang digunakan. Teknik IB yang umum digunakan adalah menggunakan semen beku pada ternak sapi dan semen cair pada ternak babi. Dalam proses pembuatan semen beku nutrisi yang terdapat pada pengencer yang digunakan sangat berperan penting untuk melindungi spermatozoa saat proses penurunan suhu agar tidak terjadinya kejutan dingin pada spermatozoa. Afiati 
(2013) menyatakan bahwa IB merupakan salah satu teknik perkawinan buatan dengan menggunakan semen dari pejantan yang telah diseleksi dan tanpa adanya kehadiran pejantan secaralangsungdengan tujuan untuk memperoleh ternak yang unggul dari segi kualitas maupun kwantitas serta menghindari perkawinan sedarah/inbreeding dan menghindari penularan penyakit.

Dalam pelaksanaan IB, petugas inse minasi/ inseminator haruslah orang memiliki keterampilan melakukan IB. Keterampilan tersebut dapat diperoleh dengan mengikuti pelatihan-pelatihan pelaksanaan IB.Berkenaan dengan uraian tersebut, maka dalam rangka meningkatkan populasi ternak babi, dilakukan penelitian tentang upaya pengembangannya melalui teknik inseminasi buatan di Sulawesi Utara.Tujuan penelitian ini mengevaluasi faktor- faktor dominan yang mempengaruhi upaya pengembangan populasi ternak babi melalui kawin Inseminasi Buatan (IB) di Provinsi Sulawesi Utara.

\section{METODE PENELITIAN}

Penelitian ini menggunakan menggunakan semen pejantan bangsa babi Landrace, Yorkshire dan Duroc dengan induk babi bangsayang sama untuk dikawinkan dengan teknik inseminasi buatan (IB). Data anak (litter size) berjumlah 345 ekor dari sejumlah sampel induk sebanyak 33 ekor yang dikawinkan dengan teknik IB digunakan dalam penelitian ini. Pengumpulan data (reproduksi induk babi betina dan produksi anak hasil IB) dilakukan melalui metode pengamatan dilaboratorium dan di lapangan ternak milik masyarakat Kabupaten Minahasa Provinsi Sulawesi Utara yang telah menerapkan Inseminasi Buatan Ternak Babi.Data dianalisis dengan menggunakan uji-t (Byrkit 1987) untuk menentukan pengaruh gender terhadap berat anak lahir dan anak babi sapihan. Semua perbandingan dilakukan pada level signifikan 5\%.Dalam penelitian ini, dilakukan prediksi faktor-faktor yang mempengaruhi efisiensi reproduksi (Y), yaitu $\mathrm{X}_{1}=$ Lama Bunting Induk (h), $\mathrm{X}_{2}=$ Jumlah Litter Size (LS) dan $\mathrm{X}_{3}=$ Rasio rasio jantan terhadap betina Litter Size; prediksi faktor-faktor yang mempengaruhi efisiensi service IB (Y), yaitu $\mathrm{X}_{1}=$ Jumlah IB per Kebuntingan, $\mathrm{X}_{2}=$ Jumlah Litter Size (LS) dan $X_{3}=$ rasio jantan terhadap betina Litter Size; dan Prediksi faktor-faktor yang mempengaruhi Weaning Average Daily Gain anak sapihan $(\mathrm{Y})$, yaitu $\mathrm{X}_{1}=$ Berat Anak Lahir (g), $\mathrm{X}_{2}=$ Berat Anak Sapihan (g) dan $\mathrm{X}_{3}=$ Umur Penyapihan Anak (hari).

\section{HASIL DAN PEMBAHASAN}




\section{a. Service per conception}

Performans induk babi betina dikawinkan melalui Teknik Inseminasi Buatan (IB) terlihat pada Gambar 1. Rataan angka service per conception (S/C), conception rate $(\mathrm{CR})$, return to service, dan farrowing rate terlihat pada Gambar 1. Rataan angka S/C dalam penelitian ini adalah 1,12 . Hal ini menunjukkan bahwa untuk mendapatkan kebuntingan untuk 100 ekor induk babi dibutuhkan pelayanan (service) inseminasi buatan (IB) sebanyak 112 straw semen pejantan. Buchanan andJohnson(1984) melaporkan hasil penelitian persilangan secara alami antarabangsa/ breed Duroc, Landrace dan Yorkshire mendapatkan angka S/C terendah 1,05 dan tertinggi 1,36 dengan rataan 1,14 \pm 0,04. Dengan demikian rataan hasil $\mathrm{S} / \mathrm{C}$ penerapan IB ternak babi di Sulawesi Utara berada pada angka lebih efisien dibandingkan dengan angka S/C peneliti sebelumnya tersebut dengan menggunakan perkawinan secara alami.

\section{b. Farrowing rate (FR)}

Dalam kajian penelitian ini, performans induk babi betina dikawinkan melalui Teknik Inseminasi Buatan (IB) terlihat pada Gambar 1. Rataan angka untuk farrowing rate adalah 10,36. Angka ini menunjukkan bahwa pada setiap induk bunting pertama setelah dilakukan kawin IB dapat menghasilkan kisaran jumlah anak liiter size sebanyak 10 sampai 11 anak (Sobczynska,et al. 2013; Soltesz and Balogh, 2013.). Buchanan and Johnson(1984) melaporkan hasil penelitian persilangan breed Duroc, Landrace dan Yorkshire mengdapatkan rataan angka FR 10,11 \pm 0,44. Angka FR dalam kajian ini adalah sejalan dengan hasil penelitian oleh peneliti tersebut yang menggunakan 128 ekor induk babi betina dalam persilangan secara alam dengan melibatkan tiga bangsa /breed babi Yorkshire, Landrace dan Duroc.

\section{c. Efisiensi Service IB (ESIB)}

Variabel ESIB diamati pada induk babi betina yang melibatkan data tentang jumlah anak litter size pada satu induk. Performans induk babi betina dikawinkan melalui Teknik Inseminasi Buatan (IB) terlihat pada Gambar 1. 


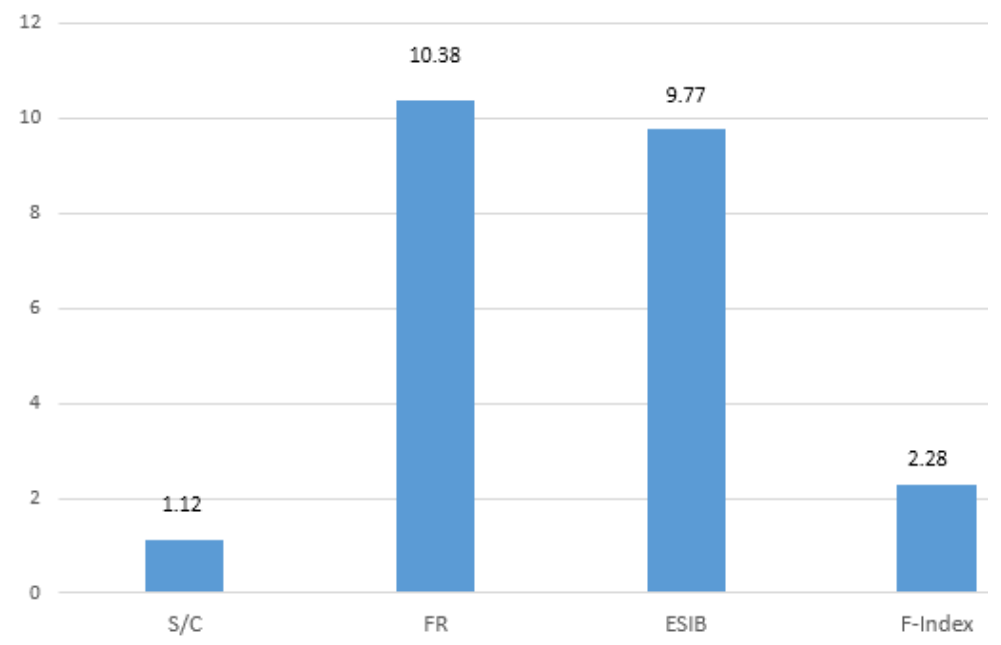

Gambar 1. Performans Induk Babi Betina Dikawinkan Melalui Teknik Inseminasi Buatan (IB). Keterangan: $\mathbf{S} \boldsymbol{C}=$ Service per conception, $\boldsymbol{F R}=$ Farrowing rate, $\boldsymbol{E S I B}=$ Efisiensi service $I B, F$-Index $=$ Farrowing index

Variabel ESIB dalam kajian ini dihitungan dari rasio jumlah anak liiter size dengan jumlah induk betina yang dilayani dengan perkawinan IB atau jumlah itter size (LS) per kelahiran dibahagi jumlah pelayanan IB (IB services). Angka variable ESIB terhadap 33 ekor induk babi betina dalam penelitian ini adalah 9,77 $\pm 2,37$. Koefisien keragaman adalah 24,26\% yang menunjukkan bahwa keragaman variable ESIB ini lebih tinggi dari 15\%, sehingga dapat dikategorikan sangat tinggi (Kurnianto, 2010).

Dengan kawin alam seekor pejantan sekali kawin atau sekali eyakulasi dengan jumlah semen berkisar 300 sampai $400 \mathrm{ml}$, jika terjadi konsepsi hanya dapat menghasilkan litter size atau farrowing rate 10 sampai 11 ekor. Jika dilakukan penampung semen sekali eyakulasi (300 $400 \mathrm{ml}$ ) dapat diencerkan menjadi rata-rata 10 straw untuk digunakan dalam pelayanan kawin IB, maka semen dari sekali eyakulasi pejantan ini dapat digunakan untuk 10 ekor induk abi betina.

Induk babi betina estrus dapat dilayani dengan kawin IB menggunakan satu straw, sehingga satu kali eyakulasi semen oleh pejantan dapat dipakai untuk 10 ekor induk babi betina. Dengan demikian, angka rata-rata ESIB 9,77 memberi arti bahwa setiap 100 kali pelayanan IB atau seratus straw semen yang dipakai untuk IB dapat menghasilkan 977 ekor litter size perkelahiran oleh induk babi betina. Jumlah 100 straw ini dapat diperoleh dari rata-rata 10 kali eyakulasi semen pejantan. Hal ini dapat memberi makna bahwa dengan kawin 
IB, potensi pejantan dapat ditingkat 10 kali lebih tinggi dibandingkan dengan perkawinan secara alam.

\section{d. Farrowing index (F-Index)}

Farrowing index adalah jumlah frekuensi beranakseekor induk babi betina dalam periode 365 hari atau selama satu tahun (Xue et al.1994; Poleze et al. 2016; Serenius et al. 2008.). Jika umur menyusui 8 minggu potensi farrowing index bisa memberi angka 2 (Sasaki and Koketsu. 2011; Segura-Correa, et al. 2011;Phengvilaysouk et al. 2017); selanjutnya jika umur penyapihan dilakukan pada umur 3 minggu, maka potensi farrowing index boleh mencapai 2,5 (Poore and Fowden, 2014; Poleze et al. 2016; Saitoet al. 2011).

Hasil pengamatan terhadap 33 ekor indukbabi betina yang dikawinkan melalui IB diperoleh angka rata-rata F-Index sebesar $2,28 \pm 0,086$. Koefisien keragaman F-Index ini adalah 3,77\% yang menunjukkan bahwa keragaman faroowing interval ini lebih rendah dari 5\%, sehingga dapat dikategorikan sangat rendah (Kurnianto, 2010). Koefisien keragaman rendah ini memberi arti bahwa tidak banyak induk babi betina yang memiliki F-Index menyimpang jauh dari angka rata-rata F-Index yang ada. Dengan demikian, angka F-Index2,28 \pm
0,086 ini masih tergolong pada angka FIndex induk babi batina secara normal, sesuai dengan hasil pengamatan oleh peneliti-peneliti sebelumnya, dan dapat tergolong pada sebaran angka rasio kelamin yang kecil membentuk sebaran kurva normal beralas sumbu $\mathrm{X}$ yang menyempit.

Xue et al. (1994) menyatakan bahwa periode F-Indexinduk babi tergantung pada variablevariabel service per konseption, lama bunting induk, periode anak menysui (preweaning period) induk atau umur anak saat penyapihan, dan weaning to service interval. Semakin panjang periode pada salah satu variable tersebut, maka semakin berkurang pula angka F-Index seekor induk babi (Koonawootrittriron, et al. 2012; Li, et al. 2010; Onteruet al. 2011). Secara umum, performans induk babi betina dikawinkan melalui Teknik Inseminasi Buatan (IB) terlihat pada Gambar 1.

\section{e. Rasio kelamin (Sex ratio) litter size}

Rasio kelamin litter size anak babi yang dikaji dalam penelitian ini adalah perbadingan jumlah anak jantan terhadap jumlah anak betina pada setiap kelahiran anak oelh seekor induk babi betina yang dikawinkan dengan metode IB. Rasio jumlah jantan dan betina (\%) litter size (345 ekor), bobot anak lahir (BAL) dan bobot anak sapihan (BAS) dari induk babi betina 
hasil perkawinan IB terlihat pada Gambar 5 . Hasil pengamatan terhadap 33 ekor induk babi betina yang melahirkan anak dengan perkawinan IB dalam kajian ini menunjukkan rasio kelamin $0,95 \pm 0,37$. Koefisien keragaman rasio kelamin ini adalah 38,95\% yang menunjukkan bahwa keragaman rasio kelamin ini lebih tinggi dari $15 \%$, sehingga dapat dikategorikan sangat tinggi (Kurnianto, 2010). Koefisien keragaman tinggi ini memberi arti bahwa banyak induk babi betina yang memiliki rasio kelamin dengan sebaran angka jauh dari angka rata-rata rasio kelamin yang ada. Dengan demikian, angka rasio kelamin 0,95 $\pm 0,37$ ini dapat tergolong pada sebaran angka rasio kelamin yang besar membentuk sebaran kurva normal beralas sumbu $\mathrm{X}$ yang melebar.
Hasil uji Chi-square $\left(\mathrm{X}^{2}\right.$-test) rasio kelamin anak pada 33 induk babi betina kawin IB menunjukkan bahwa rasio kelamin litter size anak babi dalam penelitian ini adalah tidak menyimpang dari rasio kelamin dalam keimbangan alam (rasio 1) dengan suatu nilai probabilitas yang lebih besar dari Chi-square critical value $(0,05)$, yaitu angka Chisquare $_{\text {calculated }}(0,938169245)$. Kajian ini menggambarkan bahwa rataan rasio kelamin 0,95 pada hasil perkawinan IB adalah berbeda tidak nyata dengan rasio kelamin 1 (jumlah kelamin jantan sama dengan jumlah kelamin betina). Dari jumlah 345 anak litter size pada 33 ekor induk babi betina kawin IB, terdapat 168 anak jantan dan 177 anak betina

(Gambar

2).

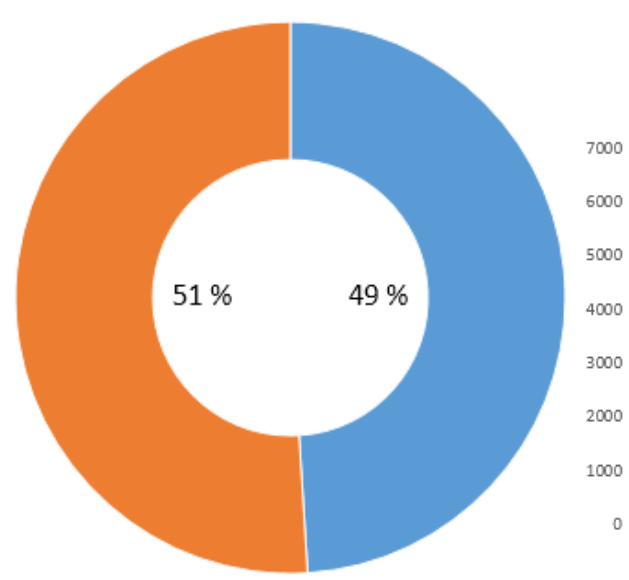

Jantan Betina

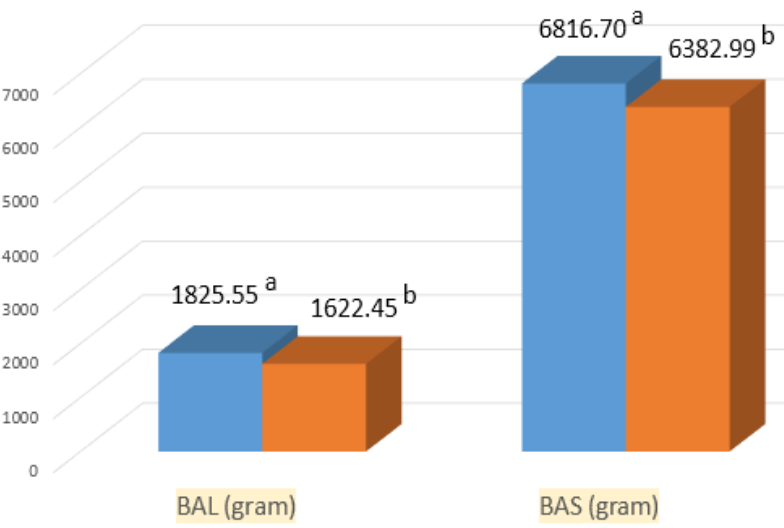

- Jantan Betina

Gambar 2.Rasio Jumlah Jantan dan Betina (\%)345 ekorLitter Size 


\section{f. Perbandingan Litter Size Inferior (LS- I) dan Litter Size Superior (LS-S)}

Jumlah anak lahir inferior (JAL-I) dan jumlah anak lahir superior (JAL-S) untuk ukuran bobot badan adalah berkisar 1 sampai 2 ekor atau rata-rata 1,54 $\pm 0,56$ ekor (JAL-I) dan 1,36 \pm 0,65 ekor (JAL-S) pada seekor induk babi betina (Tabel 4). Uji statistik (t-test) terhadap JAL-I dan JAL-S menunjukkan hasil berbeda tidak nyata pada setiap ekor induk babi betina yang dikawinkan melalui teknik IB (Gambar 3). Koefisien keragaman adalah 36,36\% (JALI) dan $45,59 \%$ (JAL-S) yang menunjukkan bahwa keragaman JAL ini lebih tinggi dari $15 \%$, sehingga dapat dikategorikan sangat tinggi (Kurnianto, 2010). Koefisien keragaman tinggi ini memberi arti bahwa banyak induk babi betina yang memiliki JAL-I dan JAL-S dengan sebaran angka jauh dari angka rata-rata JAL-I dan JAL-S yang ada. Dengan demikian, angka JAL ini dapat tergolong pada sebaran angka JAL yang besar dan membentuk sebaran kurva normal beralas sumbu $\mathrm{X}$ yang melebar.

Variabel bobot anak lahir inferior (BAL-I) dan bobot anak lahir superior (BAL-S) adalah rata-rata 1.396,21 $\pm 152,97$ gram per ekor (BAL-I) dan 2.195,64 \pm 235,97 gram per ekor (BAL-S) pada seekor induk babi betina (Gambar 3). Uji statistik (t-test) terhadap BAL-I dan BAL-S adalah berbeda sangat nyata $(\mathrm{P}<0,01)$ pada setiap ekor induk babi betina yang dikawinkan melalui teknik IB. Koefisien keragaman adalah 10,96\% (BAL-I) dan 10,75\% (BALS) yang menunjukkan bahwa keragaman BAL ini berada pada kisaran 6 sampai 14\%, sehingga dapat dikategorikan keragaman sedang (Kurnianto, 2010).

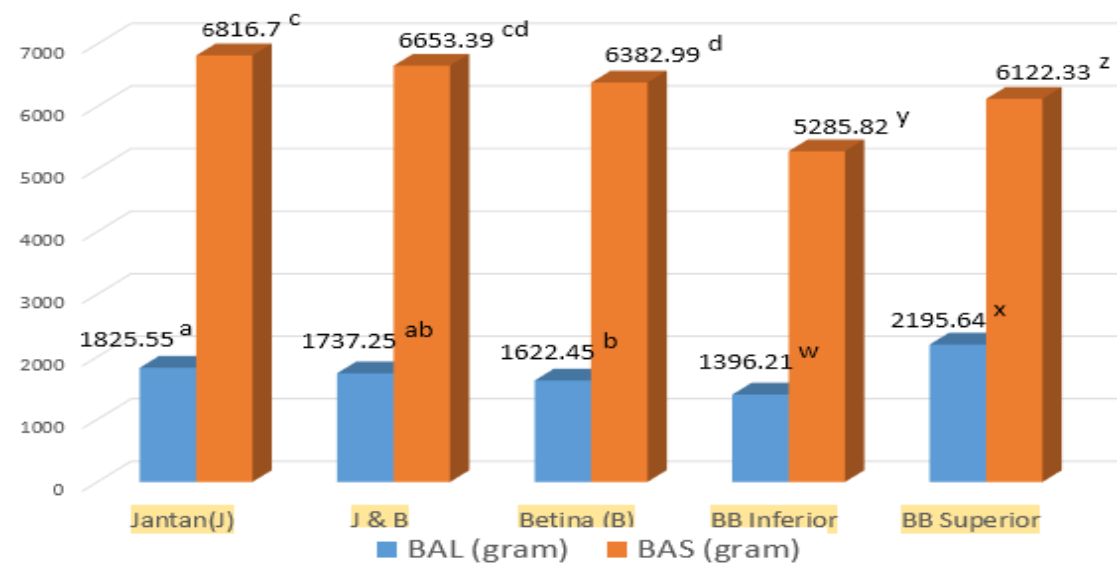

Gambar 3.Bobot Anak Lahir (BAL) dan Bobot Anak Sapihan (BAS) Dari Induk Babi Betina Hasil Perkawinan IB 
Selanjutnya, variabel bobot anak sapihan inferior (BAS-I) dan bobot anak sapihan superior (BAS-S) adalah rata-rata $5.285,82 \pm 392,66$ gram per ekor (BAS-I) dan $6.122,33 \pm 547,34$ gram per ekor $(\mathrm{BAS}$ S) pada seekor induk babi betina (Gambar 3). Uji statistik (t-test) terhadap BAS-I dan BAS-S adalah berbeda sangat nyata $(\mathrm{P}<0,01)$ pada setiap ekor induk babi betina yang dikawinkan melalui teknik IB (Gambar 3). Koefisien keragaman adalah 7,43\% (BAS-I) dan 8,94\% (BAS-S) yang menunjukkan bahwa keragaman BAS ini berada pada kisaran 6 sampai 14\%, sehingga dapat dikategorikan keragaman sedang (Kurnianto, 2010).

Variabel pertambahan bobot badan harian sebelum disapih atauPreweaning Average Daily Gain Inferior (PW-ADG-I) dan PreweaningAverage Daily Gain Superior (PW-ADG-S) telah diamati pada setiap induk babi betina yang dilakukan perkawinan melalui teknik IB. Hasil pengamatanmenunjukkan bahwa PWADG-I adalah rata-rata84,85 $\pm 8,30$ gram per ekor per hari dan PW-ADG-S adalah85,64 \pm 11,47 gram per ekor per hari (Gambar 3). Koefisien keragaman adalah 9,78\% (PWADG-I) dan 13,39\% (PW-ADG-S) yang menunjukkan bahwa keragaman PW-ADG ini berada pada kisaran 6 sampai 14\%, sehingga dapat dikategorikan keragaman sedang (Kurnianto, 2010).

Variabel PW-ADG-I dan PW-ADG$\mathrm{S}$ anak babi dalam kajian ini adalah lebih tinggi dibandingkan dengan PW-ADG anak babi yang dilaporkan oleh Abdul-Rahman et al. (2016) dan Babot, et al. (2003), yaitu 80.5 \pm 5.3 gram/hari/ekor. Kisaran PW-ADG yang lebih tinggi dari anak babi dalam kajian ini dapat disebabkan oleh faktor breed yang berbeda dan nutrisi pakan yang lebih oleh anak selama periode pre-weaning.

Uji statistik (t-test) terhadap PW-ADG -I dan PW-ADG-S menunjukkan adanya hasil rata-rata yang berbeda tidak nyata pada setiap ekor induk babi betina yang dikawinkan melalui teknik IB (Gambar 4). Kondisi ini mengindikasikan bahwa walaupun litter size dengan berat lahir inferior berbeda sangat nyata terhadap berat lahir suprior, namun PW-ADG-I dapat mengejar ketertinggalan untuk dapat menyamai PW-ADG-S, sehingga uji statistik (t-test) menunjukkan hasil yang berbeda tidak nyata (Gambar 4). Dengan demikian, faktor lingkungan dari segi pemberian nutrisi pakan dan periode laktasi induk yang baik pada anak akan dapat mengejar ketinggalan PW-ADG-I dari induk babi betina yang dikawinkan melalui teknik inseminasi buatan

(IB). 


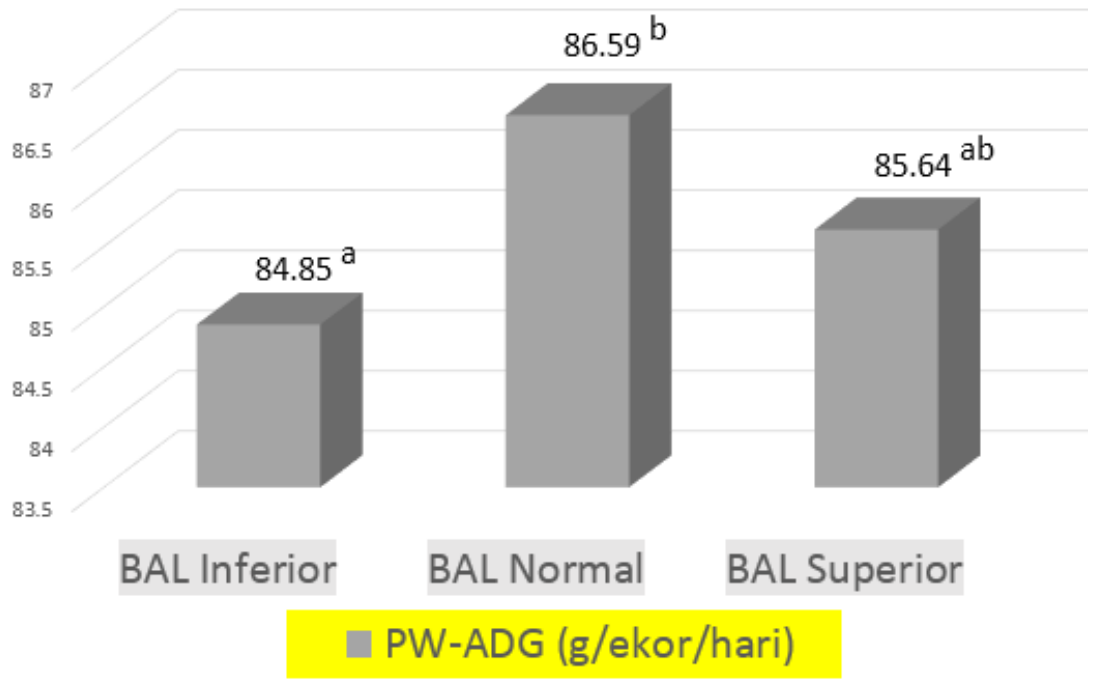

Gambar 4. Preweaning Average Daily Gain (g/ekor/hari) Pada Kelompok Berat Anak Lahir (BAL) Inferior, BAL Normal dan BAL Superior Dari Induk Babi Betina Hasil Perkawinan IB

\section{g. Faktor-Faktor Yang Mempengaruhi Reproduksi dan Produksi Induk Babi Betina Dikawinkan Melalui IB}

Untuk mengevaluasi faktor-faktor yang dapat mempengaruhi angka efisiensi service IB, maka melalui model analisis persamaan regresi berganda, dimasukkan 3 faktor independen (jumlah IB per kebuntingan induk, jumlah litter size, rasio jantan terhadap betina litter size) yang dianggap paling berpengaruh terhadap efisiensi service IB sebagai faktor dependen untuk mendapatkan angka koefisien regresi berganda $\left(b_{0}, b_{1}, b_{2}, b_{3}\right)$ pada setiap faktor independent.

Hasil analisis model persamaan regresi berganda diperoleh angka koefisien
5,16536 ( $\left.b_{0}\right),-4,95096\left(b_{1}\right), 0,95909\left(b_{2}\right)$, dan 0,20836 $\left(b_{3}\right)$, dengan angka koefisien determinan $\left(\mathrm{R}^{2}\right)$ sebesar 0,99 (Tabel 1) untuk prediksi farrowing index (Y).Hasil analisis model persamaan regresi berganda diperoleh angka koefisien 77,07258 $\left(\mathrm{b}_{0}\right)$, $0,55088\left(b_{1}\right),-0,54954\left(b_{2}\right)$, dan $-0,01311$ $\left(b_{3}\right)$, dengan angka koefisien determinan $\left(\mathrm{R}^{2}\right)$ sebesar 0,99 (Tabel 1) untuk prediksi preweaning ADG (Y). Hasil analisis model persamaan regresi berganda diperoleh angka $\mathrm{R}^{2}$ sebesar 0,99. 
Tabel 1. Hasil Analisis Faktor-Faktor Mempengaruhi Variabel Reproduksi dan Produksi Induk Babi Betina Dikawinkan Melalui IB

\begin{tabular}{|c|c|c|c|c|c|}
\hline No. & $\begin{array}{l}\text { Variabel } \\
\text { Dependen }\end{array}$ & $\begin{array}{l}\text { Model Analisis Regresi Berganda } \\
\text { Pengaruh Faktor-Faktor } \\
\text { Independen }\end{array}$ & Koe & rganda & $\mathrm{R}^{2}$ \\
\hline 1. & $\begin{array}{l}\text { Prediksi } \\
\text { variabel } \\
\text { efisiensi } \\
\text { service IB } \\
\text { (Y) }\end{array}$ & $\begin{array}{l}\mathrm{Y}=\mathrm{b}_{0}+\mathrm{b}_{1} \mathrm{X}_{1}+\mathrm{b}_{2} \mathrm{X}_{2}+\mathrm{b}_{3} \mathrm{X}_{3} \\
\mathrm{X}_{1}=\text { Jumlah IB } / \text { Kebuntingan } \\
\mathrm{X}_{2}=\text { Jumlah Litter Size }(\mathrm{LS}) \\
\mathrm{X}_{3}=\text { Rasio Male/Female LS }\end{array}$ & $\begin{array}{l}b_{1} \\
b_{2} \\
b_{3}\end{array}$ & $\begin{array}{r}5,16536 \\
-4,95096 \\
0,95909 \\
0,20836\end{array}$ & $\mathrm{R}^{2}=0,99$ \\
\hline 2. & $\begin{array}{l}\text { Prediksi } \\
\text { variabel } \\
\text { Farrowing } \\
\text { Index (Y) }\end{array}$ & $\begin{array}{l}\mathrm{Y}=\mathrm{b}_{0}+\mathrm{b}_{1} \mathrm{X}_{1}+\mathrm{b}_{2} \mathrm{X}_{2}+\mathrm{b}_{3} \mathrm{X}_{3} \\
\mathrm{X}_{1}=\text { Lama Bunting Induk } \\
\mathrm{X}_{2}=\text { Weaning to Service Interval } \\
\mathrm{X}_{3}=\text { Siklus Reproduksi Induk }\end{array}$ & $\begin{array}{l}b_{0} \\
b_{1} \\
b_{2} \\
b_{3}\end{array}$ & $\begin{array}{r}77,07258 \\
-0,55088 \\
-0,54954 \\
-0,01311\end{array}$ & $\mathrm{R}^{2}=0,99$ \\
\hline 3. & $\begin{array}{l}\text { Prediksi } \\
\text { variabel Pre- } \\
\text { weaning } \\
\text { ADG }(Y)\end{array}$ & $\begin{array}{l}\mathrm{Y}=\mathrm{b}_{0}+\mathrm{b}_{1} \mathrm{X}_{1}+\mathrm{b}_{2} \mathrm{X}_{2}+\mathrm{b}_{3} \mathrm{X}_{3} \\
\mathrm{X}_{1}=\text { Bobot Anak Lahir }(\mathrm{g}) \\
\mathrm{X}_{2}=\text { Bobot Anak Sapihan }(\mathrm{g}) \\
\mathrm{X}_{3}=\text { Umur Penyapihan Anak(h) }\end{array}$ & $\begin{array}{l}b_{1} \\
b_{2} \\
b_{3}\end{array}$ & $\begin{array}{r}89,374 \\
-0,0214 \\
0,1212 \\
-1,8850\end{array}$ & $\mathrm{R}^{2}=0,99$ \\
\hline
\end{tabular}

ADG = Average Daily Gain (Pertambahan bobot badan harian, g/ekor/hari), IB = Inseminasi Buatan (Artificial Insemination), $\mathrm{R}^{2}=$ Koefisien Determinasi.

Koefisien determinan ini menunjukkan 99 persen variasi variabel bebas $\left(\mathrm{X}_{1}, \mathrm{X}_{2}, \mathrm{X}_{3}\right)$ yang digunakan dalam model ini mampu menjelaskan variasi variabel tidak bebas (Y) dalam model, sedangkan 1 persen ditentukan oleh faktor lain (Byrkit, 1987).Dari ketiga faktor independen dalam model regresi berganda, maka diantara koefisien regresi $\left(b_{1}, b_{2}\right.$, dan $\mathrm{b}_{3}$ ), terdapat faktor $\mathrm{X}_{1}$ memiliki angka koefieisn regresi $\left(b_{1}\right)$ tertinggi, diikuti angka koefisien regresi $\left(b_{2}\right)$ untuk factor $X_{2}$ dan $b_{3}$ untuk faktor $X_{3}$. Faktor $X_{n}$ lainnya pula memiliki koefisien regresi $\left(b_{n}\right)$ tertinggi sebagai factor paling dominan dalam model.

\section{h. Peran Perkawinan Teknik Inesiminasi Buatan (IB) Terhadap Reproduksi dan Produksi Induk Babi Betina}

Jumlah induk babi Betina yang dapat dilayani sekali eyakulasi pejantan melalui kawin alam (KA) adalah hanya 1 ekor saja, sedangkan jumlah induk babi betina yang 
dapat dilayani sekali eyakulasi pejantan melalui teknik IB mencapai 10 ekor. Hal ini dapat terjadi karena semen per eyakulasi $( \pm$ $400 \mathrm{ml}$ ) dari babi pejantan dapat diencerkan dan dibahagi menjadi 10 straw $( \pm 40$ ml/Straw) untuk digunakan pada kawin IB dengan dosis 1 straw per induk babi betina estrus. Volume semen babi pejantan sekali eyakulasi setiap perkawinan (ml/Induk) adalah $\pm 40 \mathrm{ml}$ induk, sedangkan perkawinan alam, setiap perkawinan digunakan $\pm 400 \mathrm{ml} /$ induk.

Rataan jumlah litter size (LS) anak per induk betina bunting per eyakulat pejantan melalui kawin alam dapat menghasilkan rata-rata 10,4 ekor LS per eyakulat semen pejantan, sedangkan jumlah LS anak per induk Betina bunting per eyakulat pejantan melalui kawin IB dapat mencapai rata-rata 98 ekor LS per eyakulat semen pejantan. Farrowing index (jumlah kebuntingan seekor induk per tahun) adalah hanya berkisar 2,0 (Buchanan and Johnson, 1984; Sudhakar and Gaur, 2013;Holm et al. 2005; Abdul-Rahman, 2016), sedangkan hasil pengamatan dalam kajian ini mencapai angka rata-rata 2,30. Angka farrowing rata (RT) dalam kajian ini mencapai 10,4 ekor LS per eyakulat pejantan dengan KA, sedangkan efisiensi service IB (ESIB) ratarata 9,8 ekor LS per service IB.
Berdasarkan data teramati di atas, maka jumlah litter size anak dihasilkan seekor pejantan per tahun melalui kawin alam (KA) hanya dapat mencapai rata-rata 21 ekor, sedangkan jumlah litter size anak dihasilkan seekor pejantan per tahun melalui kawin IB mencapai 225 ekor.

\section{KESIMPULAN}

1. Variabelreproduksi yang dominan mempengaruhi populasi ternak babi kawinIB di Provinsi Sulut adalahService per conception (1,20), Farrowing rate (10,38 anak litter size), Efisiensi service IB (9,77 anak liiter size), dan Farrowing index (2,3 kebuntingan per tahun).

2. Preweaning Average Daily Gain (PWADG) pada kelompok bobot anak lahir inferior $(84,85 \mathrm{~g} / \mathrm{ekor} / \mathrm{hari})$ berbeda sangat nyata dengan bobot anak lahir normal (86,59g/ekor/hari), tetapi berbeda tidak nyata dengan PW-ADG dari kelompok bobot anak lahir superior $(85,64$ g/ekor/hari) pada induk babi betina hasil perkawinan IB.

3. Litter size anak dari seekor pejantan per tahun melalui kawin alam hanya dapat mencapai rata-rata 21 ekor, sedangkan litter size anak dari seekor pejantan per tahun melalui kawin IB dapat mencapai 225 ekor dalam upaya peningkatan populasi ternak babi di Sulawesi Utara. 


\section{DAFTAR PUSTAKA}

Abdul-Rahman, I, I., P. Semaha and M. Yaro. 2016. Pre and post-weaning growth performance of Ashanti Black pigs under Guinea Savanna conditions. Livestock Research for Rural Development 28 (2): 126

Afiati, F. 2013. Pembibitan Ternak dengan Inseminasi Buatan. Penebar Swadaya. Jakarta.

Babot, D., E.R. Chavez and J. Noguera. 2003. The effect of age at the first mating and herd size on the lifetime productivity of sows. Animal Research 52: 49-64.

Buchanan, D.S. and R.K. Johnson. 1984. Reproductive performance for four breeds of swine: Crossbred females and purebred and crossbred boars. Paper No. 4302 Journal series, Oklahoma Agr. Exp. Sta., Stillwater and a contribution from Regional ProjectNC-103. Genetic Improvement of Efficiency in the Production of Quality Pork.

Byrkit, D.R. 1987. Statistics Today: A Comprehensive Introduction. The Benjamin/Cummings Publishing Company, Inc. 2727 Sand Hill Road Menlo Park, California, 94025, USA.

Holm B. M. Bakken, O. Vangen and R. Rekaya. 2005. Genetic analysis of age at first service, return rate, litter size, and weaning-to-first service interval of gilts and sows. J. Anim. Sci. 83:41-48.

Koonawootrittriron, S., U. Nopibool, M.A. Elzo and T. Suwanasopee. 2012. Length of productive life and lifetime production of Landrace, Yorkshire and crossbred sows raised under Thai tropical conditions. Journal of Animal Science 90(ESuppl 3) 640.

Kurnianto, E. 2010. Ilmu Pemuliaan Ternak. Edisi Pertama, Cetakan Pertama.
Badan Penerbit, Universitas Diponegoro, Semarang. Page 13.

Li, Y., L. Johnston and A. Hilbrands. 2010. Pre-weaning mortality of piglets in a bedded group-farrowing system. Journal of Swine Health and Production. 18(2):75-80.

Onteru S. K., B. Fan, M. T. Nikkila, D. J. Garrick, K. J. Stalder, and M. F. Rothschild. 2011. Whole-genome association analyses for lifetime reproductive traits in the pig. J. Anim. Sci. 89:988-995.

Phengvilaysouk, A., A. Jansson, P. Phengsavanh, T. Tiemann, V. Phengvichith and J. E. Lindberg. 2017. Sow and piglet management in small-holder and larger-scale pig farms in Northern part of Laos. Livestock Research for Rural Development 29 (10): 127

Poleze, E., M.L. Bernardi, W.S. Amaral Filha, IvoWentz, F.P.Bortolozzo. 2016. Consequences of variation in weaning-to-estrus interval on reproductive performance of swine females.Livestock Science. Volume 103 (1-2) : 124-130.

Poore, K. R. and A.L. Fowden. 2014. Insulin sensitivity in juvenile and adult pigs of low and high birth weight. Diabetologia 47: 340-348.

Saito, H., Y. Sasaki and Y. Koketsu. 2011.Associations between Age of Gilts at First Mating and Lifetime Performance or Culling Risk in Commercial Herds. Journal of Veterinary Medicine Sciences 73: 555-559.

Sasaki, Y. and Y. Koketsu. 2011. Reproductive profile and lifetime efficiency of female pigs by culling reason in high-performing commercial breeding herds. Journal of Swine Health and Production 19: 284-291. 
Segura-Correa, J.C., E. Ek-Mex, A. AlzinaLópez, J.G. Magaña-Monforte, L. Sarmiento-Franco and R.H. SantosRicalde. 2011.Length of productive life of sows in four pig farms in the tropics of Mexico. Tropical Animal Health and Production 43: 11911194.

Serenius T., K. J. Stalder and R. L. Fernando. 2008. Genetic associations of sow longevity with age at first farrowing, number of piglets weaned, and wean to insemination interval in the Finnish Landrace swine population. J. Anim. Sci. 86:3324-3329.

Sihombing, D. T. H. 2006. Ilmu Ternak Babi. Gadjah Mada University Press, Yogyakarta.

Sobczynska, M., T. Blicharski and M. Tyra. 2013. Relationships between longevity, lifetime productivity, carcass traits and conformation in
Polish maternal pig breeds. Journal of Animal Breeding and Genetics 130, 361-371.

Soltesz, A. and P. Balogh. 2013. Investigation of lifetime performance in Dutch Large White $\times$ Dutch Landrace crossbred sows. Scientific Papers: Animal Science and Biotechnoly 46: 79-82.

Sudhakar, K. and G.K. Gaur. 2013. Preweaning growth in indigenous pigs of eastern region. Indian veterinary Research Institute. Lzatnagar, uttar Pratesh 243 122, India. Indian Journal of Animal Sciences 73 (10): 1182-1183.

Xue, J.L., G.D. Dial, W.E. Marsh, P.R. Davies.1994. Seasonal variation of reproductive performance of female swine. Journal of the American Veterinary Medical Association 204 (9):1486-1489. 